in the conditions of European integration changes, the training cycle of formation of professional competence in the system of professional training of future masters of pharmacy has been designed.

In the process of experimental training on the thematic plan of the training cycle of professional competence formation in the system of professional training of future masters of pharmacy the method and technology of case-study of solving model situations in professional pharmaceutical activity and qualimetric self-assessment questionnaires of professional masters of pharmacy on thematic sections of the training cycle are used.

An interactive seminar-briefing was held using an interactive method, reports were heard in the classroom and in a video conference, student presentations were discussed based on the results of individual creative projects in Management and Marketing in Pharmacy, interactive discussion of problem situations in professional pharmaceutical activities under conditions of European integration.

The design of the training cycle of professional competence in the system of professional training of future masters of pharmacy is integrated and includes training seminars, discussions on the results of independent work and individual projects of students in management and marketing in pharmacy, which is a reference for industry and educational, interactive methods in the experimental implementation of modernization changes and student training.

Key words: masters of pharmacy, professional competence, professional training, training cycle, experimental training.

Дата надходження статті: 16.12.2020 p.

Рецензент: доктор педагогічних наук, професор Воскобойнікова Г. И.

УДК 377.09:005.336.2-027.561:631.372-051

DOI https://doi.org/10.37915/pa.vi47.161

Недашківський Р. М.*,

orcid.org/0000-0001-7613-9250

\title{
ПРОВІДНІ ДЕТЕРМІНАНТИ ФОРМУВАННЯ ПРОФЕСІЙНОЇ КОМПЕТЕНТНОСТІ МАЙБУТНІХ ТРАКТОРИСТІВ-МАШИНІСТІВ СІЛЬСЬКОГОСПОДАРСЬКОГО ВИРОБНИЦТВА
}

Стаття присвячена одній з актуальних проблем підготовки майбутніх трактористівмашиністів - формуванню їхньої професійної компетентності. Метою статті є визначення та обьрунтування педагогічних умов цзілеспрямованого формування професійної компетентності майбутніх трактористів-мащиністів сільськогосподарського виробництва. Фактори мають потенційну здатність впливати на перебіг психолого-педагогічних процесів, а дієвість їм забезпечують певні педагогічні умови. Орієнтуючись на ияю позицію вчених, у дослідженні спочатку було визначено сукупність факторів, що виливають на формування професійної компетентності майбутніх трактористів-машиністів, а потім, спираючись на результати їх аналізу, обьрунтовано основні педагогічні умови цілеспрямованого формування ияієї інтегративної якості.

у статті розглянуто етапи наукового пошуку обьрунтування педагогічних умов; на першому етапі здійснено пілотажне дослідження, щцо передбачало виявлення найважливіших факторів формування професійної компетентності майбутніх трактористів-машиністів. На основі експериментально з'ясованих факторів визначено та теоретично облрунтовано наступні педагогічні умови формування професійної компетентності майбутніх трактористів-машиністів сільськогосподарського виробництва: цุілеспрямоване формування позитивної мотивацї учнів щодо оволодіння майбутньою професійною діяльністю; рацุінальне поєднання в освітньому процесі традицุійних та інноваційних технологій

*(C) Недашківський P. М.

030380 crs 
навчання майбутніх трактористів-машиністів сільськогосподарського виробництва; організація випереджувального навчання засобами додаткових дидактичних форм (факультативи, спецкурси, студї, наукові гуртки тощо); відбір та структурування змісту освіти на основі нормативних вимог освітнього стандарту та варіативної регіонально спрямованої складової; створення сприятливого інформаційно-освітнього середовищза для самоосвітньої діяльності учнів.

Ключові слова: педагогічні умови, фактори, майбутній тракторист-машиніст, професійна компетентність, експертна оцинка.

Постановка проблеми. Сучасний період соціально-економічного розвитку характеризується глобальними змінами технологій виробництва продукції, зокрема сільськогосподарської. На виконання цих стратегічних завдань спрямовані всі складові педагогічного процесу підготовки майбутніх трактористів-машиністів сільськогосподарського виробництва: зміст, методи, засоби та форми навчання й виховання, контроль і корекція результатів навчальної діяльності учнів при широкому залученні сучасних технологій. Високі технологї̈, науково-технічні ідеї та розробки, загалом наукомістка продукція є головною рушійною силою стійкого розвитку будьякої країни. Сучасний випускник має бути підготовлений до швидкого реагування на зміни вимог вітчизняного та міжнародних ринків праці, бути професійно мобільним, здатним до самоосвіти, самовдосконалення. Тому проблема пошуку та реалізації дієвих чинників у практиці формування професійної компетентності майбутніх трактористівмашиністів сільськогосподарського виробництва наразі є вкрай актуальною.

Аналіз досліджень. Проблеми продуктивної підготовки фахівців сільськогосподарського виробництва, які вододіють високою професійною кваліфікацією, здатностями успішно реалізовувати власний творчий потенціал на вітчизняному та світовому ринках, були предметом наукового пошуку таких учених, як: М. Артюшина, Г. Васянович, Р. Гуревич, О. Діденко, О. Сжова, Г. Ельникова, Д. Закатнов, Д. Карташова, Н. Кудикіна, А. Аитвин, П. Лузан, Г. Аукяненко, В. Манько та ін.

Сьогодні сучасна система аграрної освіти спрямована на вирішення складних завдань формування всебічно розвинутої особистості майбутнього фахівця-аграрника, розвиток його талантів, розумових і фізичних здібностей, відповідно до потреб суспільства та аграрної галузі. Тому першочергового значення набуває визначення сприятдивих педагогічних умов цілеспрямованого формування професійної компетентності майбутніх трактористів-машиністів сільськогосподарського виробництва як теоретичного базису розроблення докладних методик і технологій теоретичної та практичної підготовки здобувачів професійно-технічної освіти.

Метою статті є визначення та обгрунтування педагогічних умов цілеспрямованого формування професійної компетентності майбутніх трактористівмашиністів сільськогосподарського виробництва.

Виклад основного матеріалу. На жаль, сучасна освітня практика поки що не може задоводьнити соціальні запити підготовки трактористів-машиністів сільського господарства, які володіють високою кваліфікацією, креативними професійними якостями, здатностями успішно реалізовувати свій творчий потенціал на вітчизняному та світовому ринках, що зумовлено реаліями педагогічного процесу в професійно-технічних навчальних закладах. Хоча вченими й були накреслені шляхи розв'язання означених проблем, та питання про те, яким саме чином потрібно їх вирішувати, й досі задишається відкритим. Тому визначення сприятливих педагогічних факторів та умов формування професійної компетентності майбутніх трактористів-машиністів сільськогосподарського виробництва набуває важдивого значення.

У нашому дослідженні під факторами ефективного формування майбутніх трактористів-машиністів сільського господарства розуміємо стимули, сили, джерела, 
що мають потенційну здатність продуктивно впливати на якість процесів теоретичної і практичної підготовки учнів. У свою чергу, педагогічну умову визначаємо як обставину, що сприяє розвитку чи гальмуванню якогось педагогічного явища, об'єкта чи процесу.

Таким чином, фактори мають потенційну здатність впливати на перебіг психолого-педагогічних процесів, а дієвість їм забезпечують певні педагогічні умови. Орієнтуючись на цю позицію вчених, у дослідженні спочатку визначимо сукупність факторів, що впливають на формування професійної компетентності майбутніх трактористів-машиністів сільськогосподарського виробництва, а потім, спираючись на результати їх аналізу, обгрунтуємо основні педагогічні умови цілеспрямованого формування цієї інтегративної якості.

На першому етапі наукового пошуку було проведено пілотажне дослідження, яке передбачало виявлення найваждивіших факторів формування професійної компетентності майбутніх трактористів-машиністів. До дослідження було залучено педагогічних працівників Катюжанського вищого професійного училища та Бородянського професійного аграрного діцею. Респондентам було запропоновано визначити фактори, які найбільшою мірою впливають на формування та розвиток професійної компетентності майбутніх трактористів-машиністів.

За результатами аналізу запропонованих викладачами факторів було визначено 12 чинників, на які найчастіше вказували респонденти, зокрема: позитивна мотивація учнів до овододіння майбутньою професійною діяльністю, перспективи успішного працевлаштування та кар'єрного зростання, необхідність постійно поповнювати обсяг знань; відбір та структурування змісту освіти; професіоналізм викладача; проблемнопошукова організація самостійної роботи; сучасні інноваційні технології навчання (проблемно-розвивальна, тренінгові, імітаційно-ігрова, проєктна технології, урокдискусія, прес-конференція, відеоурок); організація інтелектуальної позаурочної діяльності учнів (факультативи, гуртки, спецк урси, клуби, студії тощо); володіння учнем пізнавальними уміннями; наявність у професійному навчальному закладі якісних посібників та підручників; сучасна матеріально-технічна база, яка дозволяе створити дієве інформаційно-освітне середовище навчадьного закладу; об'єктивність методів контродю навчальних досягнень учнів; вимоги викладача (майстра) щодо формування якісних знань із певного навчального предмета; комп'ютерна техніка (Internet).

Відібрані за результатами пілотажного дослідження фактори відображають основні структурні складові педагогічного процесу (педагогічна діяльність викдадача; навчально-пізнавальна діяльність учня; методи і форми навчання; зміст навчання; засоби навчання; контродь результатів навчання тощо), що зумовлюе достовірність отриманих даних та валідність процедури підотажного дослідження.

На другому етапі експериментального дослідження експертам було запропоновано проранжувати визначені фактори формування професійної компетентності майбутніх трактористів-машиністів. Сутність цього методу полягає в тому, що кожній властивості об'єкта присвоюється свій певний ранг. Причому кожним експертом, що входять в експертну групу, цей ранг присвоюеться самостійно, у резудьтаті чого виникає необхідність обробки одержаних даних із метою узгодження думок експертів. Здійснюеться цей процес за допомогою розрахунку коефіцієнта конкордації. Головна перевага методу рангів - простота здійснення.

При відборі експертів ми орієнтувалися на вимоги до них експертології як науки про проведення експертизи (відносно незалежне адміністративне становище; досвід активної роботи в даній системі; відсутність роздратування, песимізму, нещирості; інтелектуальна продуктивність; працездатність; упевненість в судженнях; почуття соціальної відповідальності тощо [5]).

За результатами експертного оцінювання було побудовано матрицю рангів для визначення місця того чи іншого фактора в загальній системі ранжування. Перевірка правильності заповнення матриці здійснювалася за контрольною сумою всіх рядків та простежено виконання умови: 
де: $\mathrm{n}$ - число факторів;

$$
\sum_{j=1}^{n} x_{i j}=\frac{(1+n) m}{2},(1)
$$

$\mathrm{m}$ - число опитуваних;

$\mathrm{x}_{\mathrm{ij}-}$ ранг j-го фактора у і-го опитуваного.

При підрахунках суми чисел у кожному з рядків виявидися рівними між собою (контрольна сума 78). У подальшому підраховувалася сума чисел у кожному стовпчику $\sum_{i=1}^{m} x_{i j}$ (суми рангів) та сума сум чисел в усіх стовпчиках $\sum_{j=1}^{n} \sum_{i=1}^{m} x_{i j}$. Сума сум чисел в усіх стовпчиках склала 2808 та співпала 3 контрольною сумою сум чисел в усіх рядках $\sum_{i=1}^{m} \sum_{j=1}^{n} x_{i j}$, тобто $\sum_{j=1}^{n} \sum_{i=1}^{m} x_{i j}=\sum_{i=1}^{m} \sum_{j=1}^{n} x_{i j}(2808=2808)$.

Зазначена процедура, насамперед, свідчить про точне дотримання вимог щодо заповнення матриці рангів, ії коректність та доцільність використання для аналізу.

Аналіз результатів експертного оцінювання значущості факторів формування професійної компетентності майбутніх трактористів-машиністів свідчить, що респонденти об'єктивно розрізняють пропоновані для ранжування чинники: континіум набраних рангів у межах від 180 до 288,5.

Сдід зазначити, що найменшу суму рангів набрав фактор «позитивна мотивація учнів до оволодіння майбутньою професійною діяльністю, перспективи успішного працевлаштування та кар'єрного зростання, необхідність постійно поповнювати обсяг знань»: $\sum_{i=1}^{m} x_{i j}=180$. На друге місце експерти поставили фактор «Сучасні інноваційні технології навчання (проблемно-розвивальна, тренінгові, імітаційно-ігрова, проєктна технології, урок-дискусія, прес-конференція, відеоурок)»- сума рангів цього фактора 197,5. Третє і четверте місце посіли фактори «Організація інтелектуальної позаурочної діяльності учнів (факультативи, гуртки, спецкурси, клуби, студії тощо)» $\left(\sum_{i=1}^{m} x_{i j}=211,5\right)$ та «Відбір та структурування змісту освіти» $\left(\sum_{i=1}^{m} x_{i j}=230,5\right)$ відповідно.

На п'ятому місці цілком виправдано виявився фактор «Сучасна матеріальнотехнічна база, яка дозволяе створити дієве інформаційно-освітне середовище навчального закладу» $\left(\sum_{i=1}^{m} x_{i j}=219\right)$.

Досить критично експерти поставилися щодо можливостей засобів навчання при залученні учнів до самоосвіти: фактори «наявність у професійному навчальному закладі якісних посібників та підручників» та «Комп'ютерна техніка (Internet)» зайняди 11 та 10 місця відповідно. Фактор «Об’єктивність методів контродю навчальних досягнень учнів» набрав найбільшу суму рангів $\left(\sum_{i=1}^{m} x_{i j}=288,5\right)$ і посів, відповідно, останнє, 12 місце.

Щоб довести правомірність зазначених висновків, необхідно виявити, чи узгоджуються думки експертів щодо вагомості факторів ранжування, треба визначити єдність думок експертів [2]. 3 цією метою використовувався коефіцієнт конкордації - це число від 0 до 1, що показуе узгодженість думок експертів при проведенні ранжирування якихось властивостей. Чим ближче значення до 0, тим узгодженість уважається більш низькою, при повній розбіжності думок експертів $\tau=0$, якщо думки експертів повністю співпадають, $\tau=1$. При величині даного коефіцієнта менше 0,3 думки експертів уважаються неузгодженими. При знаходженні ведичини коефіцієнта в діапазоні від 0,3 до 0,7 узгодженість вважається середньою. При ведичині більше 0,7 узгодженість приймається як висока.

Після відповідних розрахунків коефіцієнт єдності думок експертів у нашому дослідженні виявився рівним 0,59. Отже, за ведичиною коефіцієнта $\tau$ можна зробити 
висновок, що думки експертів щодо вагомості ранжованих факторів узгоджені між собою.

Натомість, щоб стверджувати, що узгодженість позицій експертів не є випадковою, необхідно визначити значимість коефіцієнта єдності думок $\tau$. У нашому дослідженні для цього було застосовано критерій Пірсона. Порівняння емпіричного й табличного значення критерію дозволяе зробити висновок про те, що 3 вірогідністю 95 \% можна стверджувати: значення $\tau=0,59$ не є випадковим.

Відмітимо, що визначені методом експертної оцінки фактори мають потенційну можливість уплинути на формування професійної компетентності майбутніх трактористів-машиністів при забезпеченні певних педагогічних умов. Відтак, аби вказані фактори позитивно впдинули на формування здатностей майбутнього трактористамашиніста успішно здійснювати професійну діяльність, необхідно в освітньому процесі закладу П(ПТ)О забезпечити компдекс педагогічних умов. На основі індуктивного способу встановлення причинно-наслідкових зв'язків визначаємо п'ять основних педагогічних умов формування професійної компетентності майбутніх трактористівмашиністів сільськогосподарського виробництва.

Важливість першої педагогічної умови - «цілеспрямоване формування позитивноі мотивацій учнів щодо оволодіння майбутнвою професійною діяльністю» - подягає в тому, що формування професійної готовності майбутнього фахівця бере початок та реалізується через низку взаємопов'язаних і взаємообумовлених етапів, на які звертала увагу дослідниця Г. Ковальчук [3]:

- розвиток інтересу до певного виду діядьності, основного у професійній мотивації, що здійснюється за допомогою бесід, дискусій, аналізу конкретних ситуацій як компонентів професійно-мотиваційних тренінгів;

- формування позитивних професійних ціннісних орієнтацій, які надають змогу побудувати в свідомості учня ідеальну модель майбутньої фахової діяльності, що є еталоном у професійному саморозвитку та сприяє формуванню ієрархії мотивів професійної діяльності;

- активне формування професійних умінь, необхідних для практичної діяльності, яке здійснюється під час участі учнів у змодельованих умовах конкретних професійних ситуацій i вимагае від них самостійності, ініціативності, творчого підходу, наподегливості тощо.

Проаналізувавши напрацювання I. Кузьми і здійснивши власні пошуки, ми дійшли висновку, що для формування позитивної мотивації учнів щодо овододіння майбутньою професійною діядьністю необхідно врахувати вікові особливості і забезпечити, щоб форми й методи освітнього процесу були цікавими, корисними та привабливими [4].

Якщо у традиційному навчанні увага акцентувалася на запам'ятовуванні і відтворенні інформації, то у нових умовах виникла потреба розвитку творчого (продуктивного) мислення учня, формування його комунікативних умінь та практичної підготовки до активної життедіядьності у постійно міндивому соціальному середовищі. Технодогії професійної підготовки майбутніх трактористів-машиністів повинні відповідати інноваційній технології підготовки, тому в процесі навчання вони мають трансформуватися від традиційних, академічних лекційно-семінарських до практичних, активних, інноваційних - проблемні лекції та семінари, тренінги, навчальні дискусії, аналіз конкретних професійних ситуацій, ділові, рольові ігри, круглі столи тощо. Визнання пріоритету інноваційних технологій навчання передбачає суб'єкт - суб'єктну взаємодію, виступає засобом розвитку професійних властивостей та якостей майбутніх трактористів-машиністів, зокрема професійних інтересів, ціннісних установок та світогляду, які стимулюють стійкий інтерес до майбутньої професійної діяльності. Ефективне поєднання традиційних та інноваційних методів у підготовці майбутніх трактористів-машиністів сприяе активному оволодінню учнями цілою системою вмінь і навичок. Враховуючи це, другою педагогічною умовою формування професійної 
компетентності майбутніх трактористів-машиністів визначаємо раціональне поєднання восвітньому процесі традиційних та інноваційних технологій навчання майбутніх трактористів-машиністів сільськогосподарського виробництва.

Створення умов для забезпечення формування професійної компетентності майбутніх трактористів-машиністів відбувається шляхом організації навчальної праці таким чином, щоб у кожного учня формувати уміння вчитися, виховувати наполегливість, самостійність, дисциплінованість та відповідальність, розвивати прийоми саморегуляції у комфортному навчальному середовищі.

Випереджувальне навчання є навчанням на перспективу, коли вивчення складних тем розпочинається задовго до їхнього календарного терміну. У випереджаючому навчанні до нової теми починають підходити задовго до того, як прийде ії година за програмою, - по декілька хвилин на кожному уроці, поступово, не поспішаючи [6]. Вкажемо на етапи перспективної підготовки до вивчення складаних тем. Перший етап передбачає ознайомлення учнів 3 новими поняттями теми, яка вивчається з випередженням. Проводиться активна робота зі схемами-опорами, виконуються практичні завдання з коментованим управлінням, коли кожен учень зосереджується на новому матеріалі, оволодіває новими поняттями чи способами діяльності. На другому етапі уточнюються, систематизуються знання 3 теми, відпрацьовуються прийоми професійної діяльності на узагальнених схемах. Учням пропонуються завдання для самостійного опрацювання за узагальненими схемами-опорами. На другому етапі здійснюється випередження у вивченні нового матеріалу. На останньому, третьому, етапі формуються повновартісні знання без використання схем-опор, але 3 перспективою на овододіння новими знаннями.

Ідею випереджувального навчання під час підготовки майбутніх трактористівмашиністів організовують засобами додаткових дидактичних форм (факультативи, спецкурси, студії, наукові гуртки тощо). Отже, третьою педаzогічною умовою формування професійної компетентності майбутніх трактористів-машиністів є організація випереджувального навчання учнів засобами додаткових дидактичних форм (факультативи, спецгкурси, студї, наукові гуртки тощо).

Сучасна професійна підготовка фахівців агропромислового комплексу характеризується удосконаленням навчальних планів, програм, кваліфікаційних стандартів і самої підготовки фахівців-аграрників. Як відмічае В. Радкевич, відбір і структурування змісту освіти має грунтуватися, 3 одного боку, на врахуванні результатів аналізу професій, професійних операцій, а з іншого - дидактичних підходів, принципів, критеріїв, а також ціннісних, культурологічних, компетентнісних аспектів професійної діяльності фахівців [7, с.71-77]. Висунуті вимоги до формування професійної компетентності майбутніх трактористів-машиністів на сучасному етапі вкдючають і рівень сформованих професійних умінь та навичок із відповідної робітничої кваліфікації. 3 цією метою до структури змісту професійних умінь майбутніх фахівців відносять уміння та навички з робітничої професії, зміст яких має грунтуватися на основі вимог дидактичних принципів відбору та структурування професійної підготовки.

Варто зазначити, що курси за вибором посідають особливе місце в структурі змісту навчального профілю. Вони є тим основним педагогічним засобом, який забезпечуе варіативність навчання в старшій школі, його особистісну спрямованість і дає можливість певною мірою нівелювати суперечність між єдиними державними вимогами до загальноосвітньої підготовки старшокласників та їхніми індивідуальними інтересами, нахилами і потребами. Із цього випливають дві основні функції курсів за вибором: профільно-орієнтувальна й індивідуальна навчально-пізнавальна [8, с. 6].

Відбір та структурування змісту освіти на основі нормативних вимог освітнвого стандарту та варіативної регіонально спрямованої складової освітньої програми це четверта педагогічна умова формування професійної компетентності майбутніх трактористів-машиністів. 
Основною метою навчального процесу є не лише засвоєння знань, а й оволодіння способами цього засвоєння, розвиток пізнавальних потреб і творчого потенціалу всіх, хто навчається. Навчання на основі інформаційно-комунікаційних технологій здатне забезпечити індивідуалізацію навчання, адаптацію до власних здібностей, мождивостей та інтересів тих, хто навчається, розвиток їхньої самостійності та творчості, доступ до нових джерел навчальної інформації, використання комп'ютерного моделювання процесів, що вивчаються, об'єктів і т.ін. Таким чином, мова піде про створення та використання інформаційного освітнього середовища.

Теоретики і практики сучасної психолого-педагогічної науки єдині в тому, що інформаційно-освітне середовище (IOC) - це цілісна система, яка складається зі сукупності підсистем, що функціонують і забезпечують педагогічну взаємодію учасників освітнього процесу на основі сучасних інформаційно-технічних і навчальнометодичних засобів (насамперед - інформаційно-комунікаційних технодогій) [1]. До основних функцій інформаційно-освітнього середовища належать: інформаційна, комунікативна, розвиваюча, навчальна, діагностична, рефлексійна.

Важливим фактором якості інформаційного забезпечення $є$ інформаційна інфраструктура навчального закладу. Створення такої інфраструктури є запорукою успішного впровадження інформаційних технологій в освіту на всіх іï рівнях, що дозволяє комп'ютеризувати навчальну, виховну, управлінську та будь-яку іншу діяльність навчального закладу. Тому створення сприятливого інформаційно-освітнього середовища для самоосвітньої діяльності учнів виокремлюємо як и'яту педагогічну умову формування професійної компетентності майбутніх трактористів-машиністів (рис. 1).

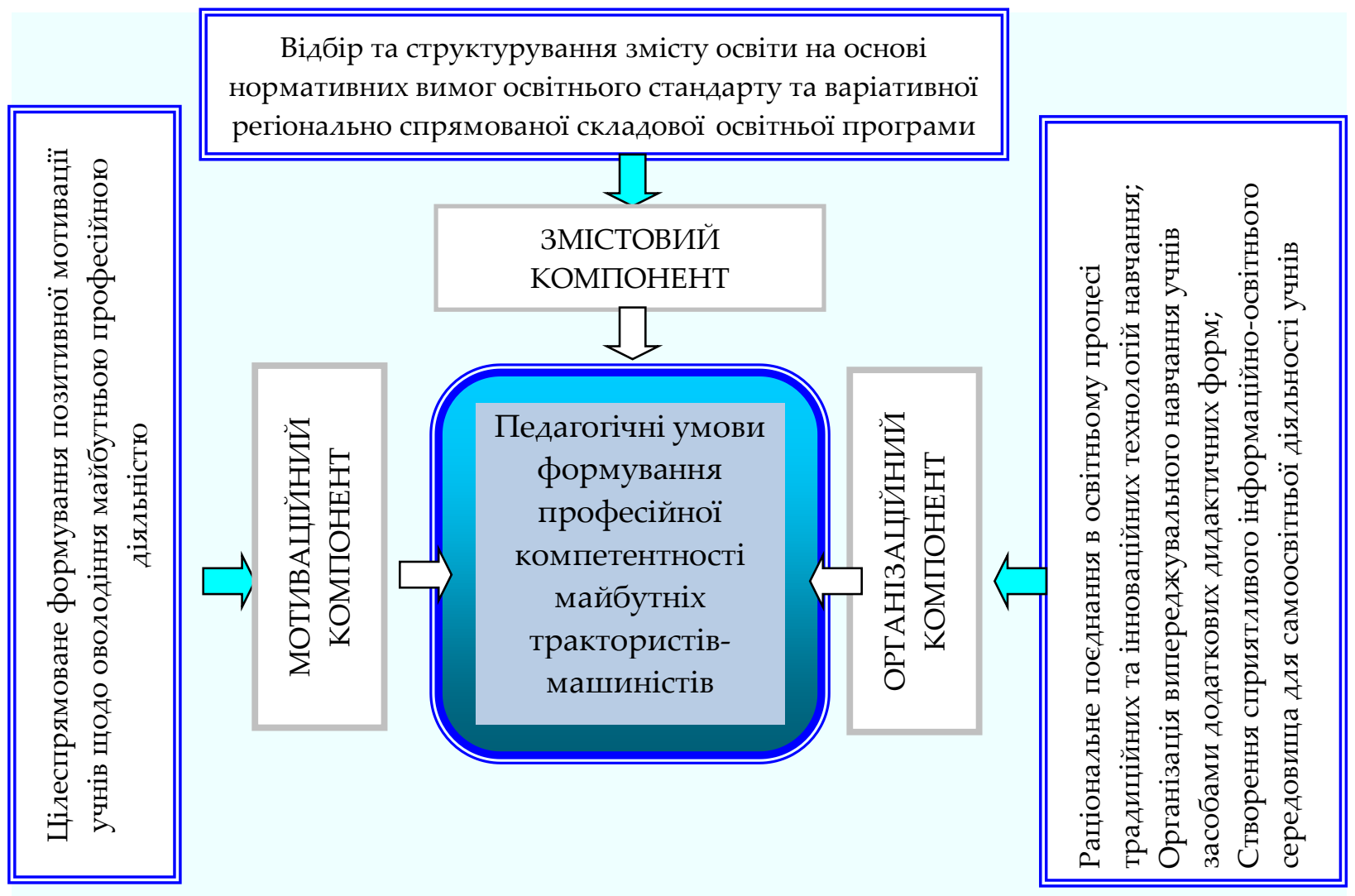

Рис. 1. Педагогічні умови формування професійної компетентності майбутніх трактористів-машиністів 
Висновки. Отже, враховуючи доробки науковців, власний досвід, результати факторного аналізу, ми визначили такі провідні педагогічні умови формування професійної компетентності майбутніх трактористів-машиністів: цілеспрямоване формування позитивної мотивації учнів щодо оволодіння майбутньою професійною діяльністю; раціональне поєднання в освітньому процесі традиційних та інноваційних технологій навчання майбутніх трактористів-машиністів сільськогосподарського виробництва; організація випереджувального навчання учнів засобами додаткових дидактичних форм (факультативи, спецкурси, студії, наукові гуртки тощо); відбір та структурування змісту освіти на основі нормативних вимог освітнього стандарту та варіативної регіонально спрямованої складової освітньої програми; створення сприятливого інформаційно-освітнього середовища для самоосвітньої діяльності учнів.

У подальших наукових розвідках зосередимо увагу на моделюванні процесу формування професійної компетентності майбутніх трактористів-машиністів сільськогосподарського виробництва.

\section{Список використаних джерел:}

1. Биков В. Ю. Моделі організаційних систем відкритої освіти: монографія. Київ: Атіка, 2008. $684 \mathrm{c.}$

2. Глас Дж., Стэнии Дж. Статистические методы в педагогике и психологии / пер. с англ. А. И. Хайрусовой. Москва: Прогресс, 1976. 494 с.

3. Ковальчук Г. О. Активізація навчання в економічній освіті: навч. посіб. / 2-ге вид., доп. Київ: KHEУ, 2003. 298 c.

4. Кузьма I. I. Формування мотивації до медіаосвіти в дітей старшого дошкільного та молодшого шкільного віку. Педагогічний альманах: збірник наукових праць / редкол. В. В. Кузьменко (голова) та ін. Херсон: КВНЗ «Херсонська академія неперервної освіти», 2020. Випуск 46. С. 32-38.

5. Дузан П. Г., Сопівник І. В., Виговська С. В. Основи науково-педагогічних досліджень. 4-е вид., доповнене. Київ: НАКККіМ, 2012. 368 с.

6. Аысенкова С. Н. Методом опережающего обучения: книга для учителя: из опыта работы. Москва: Просвещение, 1988. 192 с.

7. Радкевич В. О. Дидактичні підходи до відбору і структурування змісту професійно-технічної освіти. Сучасні інформаційні технології та інноваційні методики навчання в підготов ці фахівців: методологія, теорія, досвід, проблеми. 2010. Вип. 1. С. 71-77.

8. Фундаменталізація змісту освіти у старшій школі в умовах профільного навчання: метод. рек. / авт. кол.: Г. О. Васьківська, Н. В. Захарчук, С. В. Косянчук. Київ: Вид-во НПУ імені М. П. Драгоманова, 2015. 68 с.

\section{Reference:}

1. Bykov, V. Yu. (2008). Modeli orhanizatsiinykh system vidkrytoi osvity [Models of organizational systems of open education]. Kyiv: Atika [in Ukrainian].

2. Glas, Dzh., \& Stenli, Dzh. (1976). Statisticheskie metody v pedagogike i psikhologii [Statistical Methods in Pedagogy and Psychology]. Moskva: Progress [in Russian].

3. Kovalchuk, H. O. (2003). Aktyvizatsiia navchannia v ekonomichnii osviti [Intensification of education in economic education]. Kyiv: KNEU [in Ukrainian].

4. Kuzma, I. I. (2020). Formuvannia motyvatsii do mediaosvity v ditei starshoho doshkilnoho ta molodshoho shkilnoho viku [Formation of motivation for media education in children of senior preschool and primary school age]. Pedahohichnyi almanakh, 46, 32-38 [in Ukrainian].

5. Luzan, P. H., Sopivnyk, I. V., \& Vyhovska, S. V. (2012). Osnovy naukovo-pedahohichnykh doslidzhen [Fundamentals of scientific and pedagogical research]. Kyiv: NAKKKiM [in Ukrainian].

6. Lysenkova, S. N. (1988). Metodom operezhaiushchego obucheniia [Advance learning method]. Moskva: Prosveshchenie [in Russian].

7. Radkevych, V. O. (2010). Dydaktychni pidkhody do vidboru i strukturuvannia zmistu profesiinotekhnichnoi osvity [Didactic approaches to the selection and structuring of the content of vocational education]. Suchasni informatsiini tekhnolohii ta innovatsiini metodyky navchannia $v$ pidhotov tsi fakhivtsiv : metodolohiia, teoriia, dosvid, problemy, 1, 71-77 [in Ukrainian]. 
8. Vaskivska, H. O., Zakharchuk, N. V., \& Kosianchuk, S. V. (2015). Fundamentalizatsiia zmistu osvity u starshii shkoli v umovakh profilnoho navchannia [Fundamentalization of the content of education in high school in terms of specialized training]. Kyiv: Vyd-vo NPU imeni M. P. Drahomanova [in Ukrainian].

Nedashkivsky R. M.,

orcid.org/0000-0001-7613-9250

\title{
LEADING DETERMINANTS OF FORMATION OF PROFESSIONAL COMPETENCE OF FUTURE TRACTORS-MACHINERY OF AGRICULTURAL PRODUCTION
}

The article is devoted to one of the urgent problems of training future tractor drivers the formation of their professional competence. The purpose of the article is to determine and substantiate the pedagogical conditions for the purposeful formation of professional competence of future tractor drivers of agricultural production. Factors have the potential ability to influence the course of psychological and pedagogical processes, and their effectiveness is provided by certain pedagogical conditions. Based on this position of scientists, the study first identified a set of factors influencing the formation of professional competence of future drivers-drivers, and then, based on the results of their analysis, substantiated the main pedagogical conditions for purposeful formation of this integrative quality.

The article considers the stages of scientific research to substantiate the pedagogical conditions, at the first stage of which a pilot study was conducted, which involved identifying the most important factors in the formation of professional competence of future tractor drivers. Based on experimentally determined factors, the following pedagogical conditions for the formation of professional competence of future tractor drivers of agricultural production were determined and theoretically substantiated: purposeful formation of positive motivation of students to master future professional activity; rational combination in the educational process of traditional and innovative technologies of training future tractor drivers of agricultural production; organization of advanced training of students by means of additional didactic forms (electives, special courses, studios, scientific circles, etc.); selection and structuring of the content of education on the basis of regulatory requirements of the educational standard and a variable regionally oriented component, the creation of a favorable information and educational environment for self-educational activities of students.

Key words: pedagogical conditions, factors, future tractor-driver, professional competence, expert assessment.

Дата надходження статті: 04.01.2021 p. Рецензент: доктор педагогічних наук, професор Аузан П. Г.

\author{
У, ДК 124.5+316 \\ DOI https://doi.org/10.37915/pa.vi47.162
}

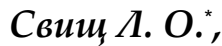

orcid.org/0000-0002-4360-9700

\section{ЦІННІСНІ ЗМІНИ ЯК ДЕТЕРМІНАНТИ ЦІННІСНОЇ ОСВІТИ}

Сучасні зміни аксіологічних орієнтирів зумовлюють динамічні процеси переосмислення цінностей, ціннісних установок, змін змісту иіннісно-смислової сфери нашого сучасника. Відтак зростае значення аксіологічних досліджень та сфера застосування аксіологічного підходу. Особливого значення набувають дослідження впливу сучасних змін аксіологічних орієнтирів на освітні пріоритети вищої щколи.

*(C) Свищ $\Lambda . O$

O3 